\title{
First report of Colletotrichum spp. causing diseases on Capsicum spp. in Sabah, Borneo, Malaysia
}

\author{
Ha Kwan Yun ${ }^{1}$, Abdul Hamid Ahmad ${ }^{2}$, Sepiah Muid ${ }^{3} \&$ Jaya Seelan Sathiya Seelan ${ }^{4}$ \\ 1,2,4 Institute for Tropical Biology and Conservation, Locked bag 2073, Universiti Malaysia Sabah, 88999, Kota Kinabalu, Sabah, Malaysia \\ ${ }^{3}$ Department of Plant Science and Environmental Ecology, Faculty of Resource Science and Technology, Universiti Malaysia Sarawak, \\ 94300 Kota Samarahan, Sarawak, Malaysia \\ Email: ${ }^{1}$ hky@yahoo.com; ${ }^{4}$ avinash80us@yahoo.com (Corresponding author)
}

Date of publication (online): 26 August 2009 Date of publication (print): 26 August 2009 ISSN 0974-7907 (online) | 0974-7893 (print)

Editor: V.B. Hosagoudar

\section{Manuscript details:}

Ms \# 02273

Received 26 May 2009

Final received 08 July 2009

Finally accepted 21 August 2009

Citation: Yun, H.K., A.H. Ahmad, S. Muid \& J.S.S. Seelan (2009). First report of Colletotrichum spp. causing diseases on Capsicum spp. in Sabah, Borneo, Malaysia. Journal of Threatened Taxa 1(8): 419-424.

Copyright: @ Ha Kwan Yun, Abdul Hamid Ahmad, Sepiah Muid \& Jaya Seelan Sathiya Seelan 2009 Creative Commons Attribution 3.0 Unported License. JoTT allows unrestricted use of this article in any medium for non-profit purposes, reproduction and distribution by providing adequate credit to the authors and the source of publication.

Author Details: See end of this article.

Author Contribution: The first author designed and conducted this study as a partial fullfilment of her BSc (Hons) degree, while the fourth author supervised her research work and gave technical advice. The second and third authors commented on the manuscript and provided extensive information during research.

Acknowledgement: The authors are grateful to Associate Professor Dr. Michael Wong, Mr. Liew Thor Seng, Mr. Lau Foo Chwang, Madam Lam Nyee Fan, Mr. Azrie Ahmad, Mr. Cornelius, Madam Fatimah Jumat and Miss Doreen Juhan for their kind help during this research.
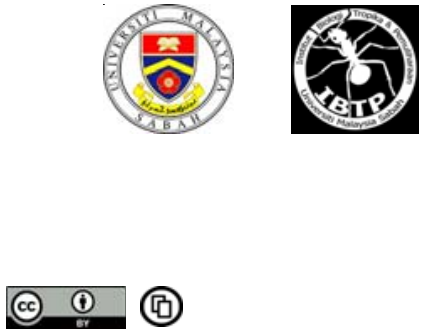

OPEN AGCESS | FREE DOWNLOAD
Abstract: Blackish or orange liquid-like spots were found on $(n=100)$ fruits of chillies (Capsicum) sold in five local markets in Kota Kinabalu, Sabah, Malaysia. Colletotrichum gloeosporioides and C. capsici were identified as the causal agents of an anthracnose disease. This is the first report of Colletotrichum spp. as the causal agent of anthracnose infected chillies in Sabah.

Keywords: Anthracnose, Colletotrichum, chillies, morphology

\section{INTRODUCTION}

The genus Capsicum comprises several species of chillies belonging to the family of Solanaceae. There are five important domesticated chilli species i.e. C. annuum, C. chinense, C. baccatum, C. frutescens and C. pubescens. This genus is native to the Americas and is now cultivated worldwide (Sanogo 2003). In Sabah, chillies are planted intensively at Kundasang, Keningau and many other areas. Chillies are important ingredients in local food and are used regularly. Anthracnose is a common disease attacking chillies in Sabah but the causal agents, the species of the genus Colletotrichum have have not been identified so far. According to Poonpolgul \& Kumphai (2007), Thailand had encountered severe losses up to $80 \%$ due to a great fall in chilli production affected by Colletotrichum spp. whereas losses which were greater than $30 \%$ in plant production occurred in the United Stated due to anthracnose (Howard et al. 1992; Wilson et al. 1992).

More seriously, five species of Colletotrichum, namely Colletotrichum coccodes, Colletotrichum crassipes, Colletotrichum dematium, Colletotrichum gloeosporioides and Colletotrichum graminicola have been reported to cause infection in humans also. These infections are keratitis following traumatic implantation, subcutaneous and systemic infections among immunosuppressed patients (Liesegang \& Forster 1980; Liao et al. 1983; Shukla 1983; Matsuzaki et al. 1988; Ritterband et al. 1997; Guarro et al. 1998; De Hoog et al. 2000; Castro et al. 2001; Yamamoto et al. 2001; Fernandez et al. 2002; Cano et al. 2004). The five species of the genus Colletotrichum known to cause similar symptoms on chillies are C. gloeosporioides, C. acutatum, C. capsici, C. cocodes and C. dematium (Hong \& Hwang 1998; Gopinath et al. 2006). This study is aimed to report the causal agents of anthracnose disease in chillies for the first time in Sabah, Borneo.

\section{Material and Methods}

Sampling: Samples were collected from five local markets in Kota Kinabalu, Sabah, Malaysia, i.e. Central Market, Menggatal Market, Donggongon Market, Lido Market and Wong Kwok Market.

Fungi isolation: The samples were brought to laboratory in a sealed plastic bag. Lesions were excised, surface sterilized with $70 \%$ ethanol for 30 s rinsed a few times with distilled water and dried on filter papers. They were cut into smaller pieces of approximately $5 \times 5 \mathrm{~mm}$ size, cultured in petri dishes containing potato dextrose agar (PDA) and incubated at room temperature, in the dark, for 48 to $72 \mathrm{hr}$.

Morphological identification: An inoculum loop was used to scratch the mycelium of the colonies and mounted on the slides. Compound microscope and scanning electron microscope were used to observe the colony colour and form, appressorium features, shape, size and colour of spores from different isolates. Identification was made by comparing the characteristics of fungi following Charlie et al. (2001) and Deacon (1998).

\section{RESULtS}

One-hundred infected chillies with symptoms of anthracnose caused by Colletotrichum 

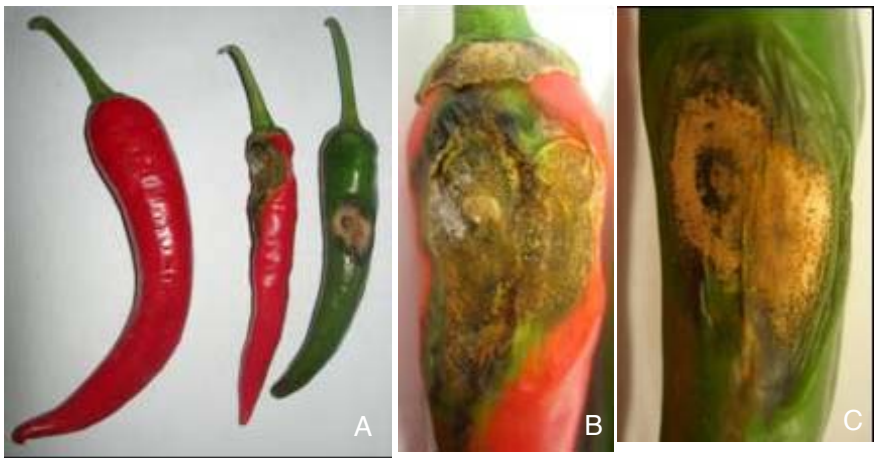

Image 1. (A) Capsicum spp.; non-infected chilli (left) and infected chillies (center and right) attacked by Colletotrichum spp.; (B) \& (C) lesions of chillies. (Photos by Ha Kwan Yun, 2008)

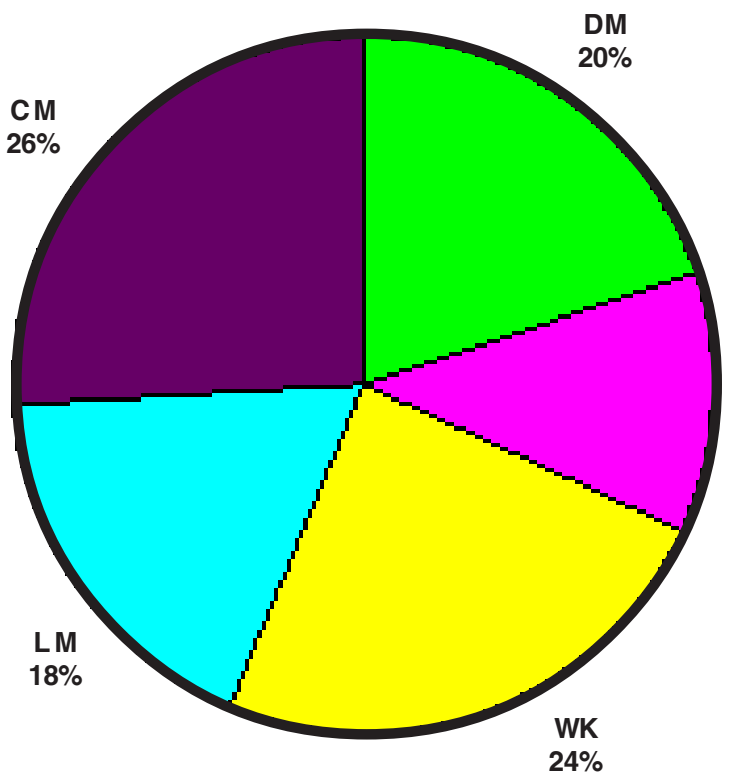

M M

$12 \%$

Figure 1. Percentage of Colletotrichum isolates obtained from five local markets.

DM - Donggongon market; MM - Menggatal market; WK - Wong Kwok market; LM - Lido market; CM - Central market

spp. were collected from the five local markets of Kundasang, Ranau areas, Papar and rural areas (Image 1). The lesions gradually turned darker, contained fluid as they matured. Lesions occured at different parts of the fruits as well as panicle in different sizes.

Out of 100 chilli samples collected, 50 isolates of Colletotrichum from the lesions, were two species i.e. Colletotrichum gloeosporioides and Colletotrichum capsici from five local markets in Sabah. Overall, the Central Market recorded the highest percentage of Colletotrichum spp. This was followed by the Wong Kwok Market and Donggongon Market which documented $24 \%$ and $20 \%$ of the total number of Colletotrichum isolates, whereas the least number of Colletotrichum isolates were from the Menggatal Market (Fig. 1). Totally 49 isolates of Colletotrichum gloeosporioides and one isolate of Colletotrichum capsici were successfully obtained. Colletotrichum gloeosporioides was mainly isolated from the Central Market followed by Wong Kwok Market. In contrast, this species was rarely found from the Menggatal Market (Table 1). Thus, the samples indicate infection mainly by Colletotrichum gloeosporioides and

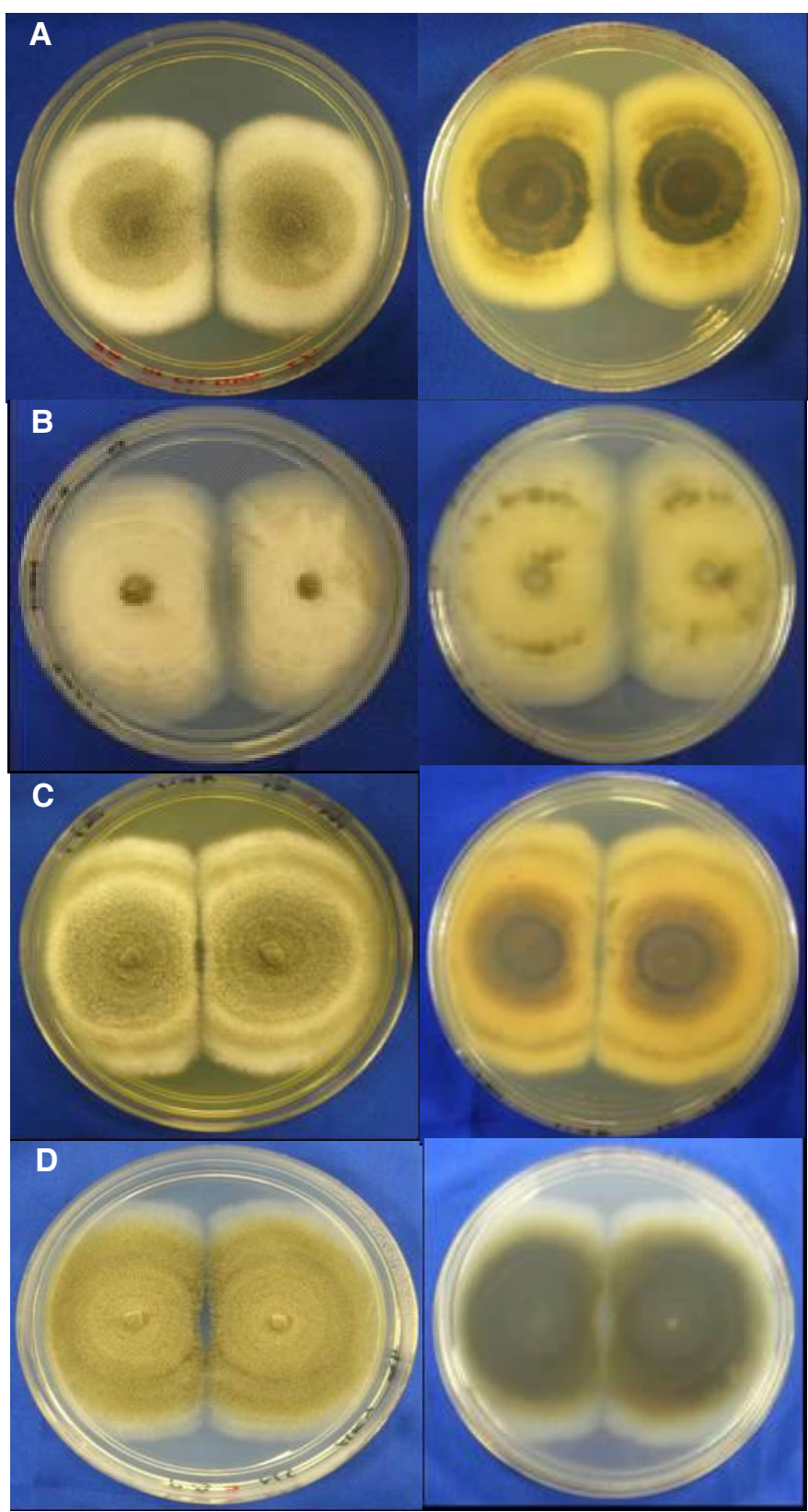

Image 2. Back and front view of different strains of Colletotrichum gloeosporioides on PDA.

A - Isolate UMS016M; B - Isolate UMS037L; C - Isolate UMS046C; D - Isolate UMS014M.

\section{Colletotrichum capsici.}

Observations of morphological characteristics of the isolates showed similarities with published descriptions of Colletotrichum spp. (Cano et al. 2004). However in this study, Colletotrichum gloeosporioides strains indicated differences in growth patterns (Image 2).

The colour of conidia obtained varied between olive and white while the reverse colour for olive colonies varied from dark olive-grey to brown. For white-coloured colonies, the reverse colour was whitish with a little olive (Image $2 \mathrm{~B}$ ). The olive coloured colony produced abundant sporulation while the white possessed sparse mycelium. Setae developed a dense, cylindrical layer around the conidiamata of the olive-coloured colonies, which gradually turned into dark olive-grey, as maturation progressed. White colonies retained their colour 


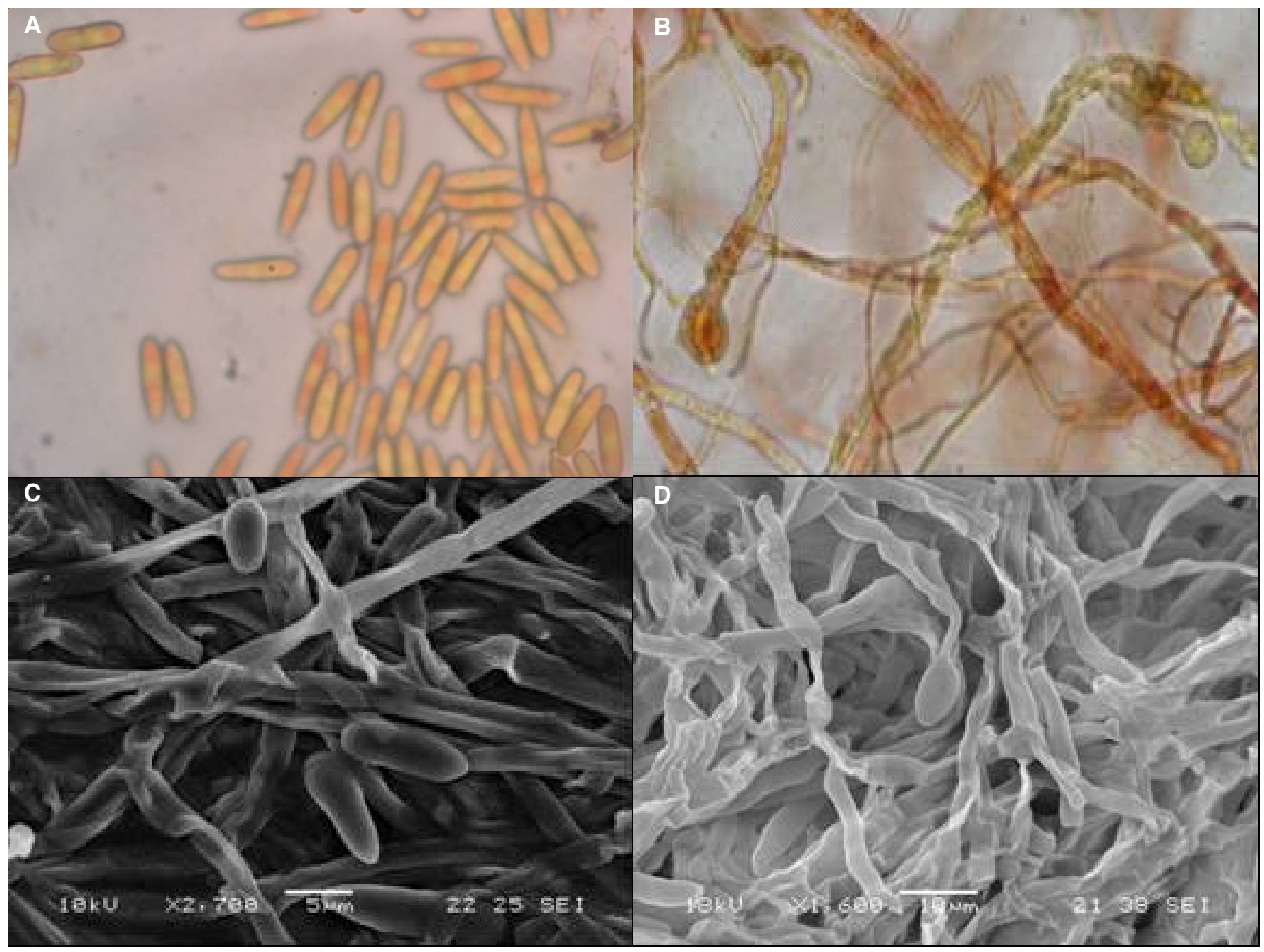

Image 3. Colletotrichum gloeosporioides

A - Conidia stained with Lugol iodine, magnification 1000x; B - Appresoria stained with Lugol iodine, magnification 1000x; C \& D - Scanning electron micrographs showing germinated conidia (c) and a globose appresorium (a) attaches to a germ tube (gt).

as they aged. Colonies of Colletotrichum spp. grew at a moderate rate, 14 days to cover the whole surface of the petri dishes. After a long-term storage, masses of conidia increased and aged into darker grayish-olive. The conidia of Colletotrichum gloeosporioides were straight with obtuse apex, hyaline, cylindrical to clavate and sometimes fusiform like Colletotrichum acutatum (Image 3). Clavate and lobed appresoria were mainly present in matured colonies. The spore measurement of Colletotrichum gloeosporioides varied between 3.93-12.14 $\mu \mathrm{m}$ long and $1.43-2.14 \mu \mathrm{m}$ wide.

\section{Colletotrichum capsici}

The isolates showed grayish-olive colonies while the reverse color was darker olive (Image 4). Sporulation of this species was sparse and the acervuli were scattered. This species formed smooth, circular margin in the colony. The gray-whitish mycelium of Colletotrichum capsici gradually developed from the isolates from the second day of culture. Colour of the colonies of Colletotrichum capsici is similar to Colletotrichum gloeosporioides. However, both of these Colletotrichum species showed distinct difference in conidia and appresoria shapes. The conidia of Colletotrichum capsici were falcate in shape while the appresoria were round to ovate in shape. The spore measurement of this species varied between 13.21-16.21 $\mu \mathrm{m}$ long and 1.79-3.28 $\mu \mathrm{m}$ wide. The conidiophores of all the colonies branched below the surface of media as they developed.

\section{Discussion}

In this study, the commonly available Capsicum annuum, $C$. baccatum and C. frutescens collected from the local markets in Kota Kinabalu, Sabah were studied. Occurrence of Colletotrichum spp. induced chilli anthracnose at the Central Market and Wong Kwok Market was higher when compared to the other three sites, most probably due to high humidity and wetness. This is consistent with the assumption of Arauz (2000) that excess moisture enables spores to be released from acervuli. On the other hand, the Menggatal Market and Lido Market smaller in size, and the stalls at Lido Market grouped into compartments according to types of goods sold decreased the percentage of humidity reduced the occurrence of chilli anthracnose.

Arauz (2000) stated that $20-30{ }^{\circ} \mathrm{C}$ range is the optimal condition for Colletotrichum gloeosporioides to form appresoria and 


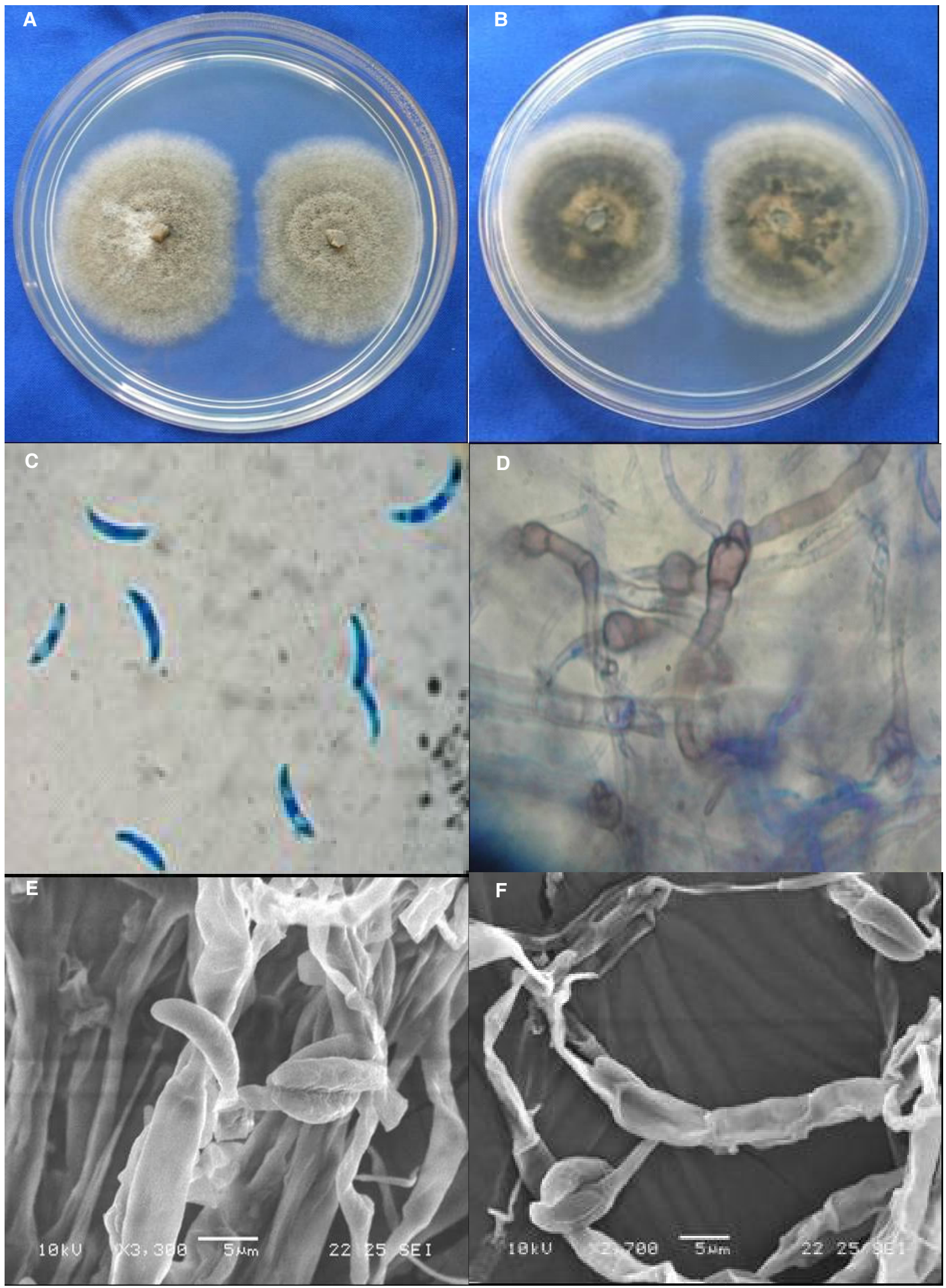

Image4. Colletotrichum capsici (UMS028WK).

A - Front view of colony growing on PDA; B - Reverse colony growing on PDA; C - Conidia stained with lactophenol blue, magnification 1000x; D - Appresoria stained with lactophenol blue, magnification 1000x; E \& F - Scanning electron micrographs showing germinated conidia (c) and a globose appresorium (a) attaches to a germ tube (gt). 
germinate). In this study, Colletotrichum gloeosporioides was found to be the most dominant pathogen (98\%), significantly more than Colletotrichum capsici, in agreement with the study of Ellett (1989) and Manandhar \& Hartman (1995).

This study reveals agreement with Black \& Wang (19932002 ) that Colletotrichum gloeosporiodes and Colletotrichum capsici were mostly found in ripe chillies collected from Kota Kinabalu, Sabah. Prusky (1996) postulated that fruits are attacked by the pathogen early in their development. The fungi remain as germinated appressorium during quiescent period 'develop brown-black spots on the pericarp and soft rot in the mesocarp when fruit ripens for harvest. Infection of chillies by Colletotrichum spp. is mainly due to ample nutrients and limited antifungal compounds formed during fruit ripening (Prusky 1996).

\section{Conclusion}

The two species of Colletotrichum spp., i.e. Colletotrichum gleoesporioides and Colletotrichum capsici were isolated from the chilli lesions collected from local markets in Kota Kinabalu, Sabah. Although Colletotrichum acutatum is reported as one of the common pathogens on chilli lesions, it was not found in this study. The conidia of Colletotrichum gloeosporioides were straight with obtuse apex, hyaline, cylindrical to clavate, and sometimes fusiform like Colletotrichum acutatum. Appresoria were mainly present in mature colonies. They were clavate and lobed. The spore measurement for this species ranged within 3.93-12.14 $\mu \mathrm{m}$ long and 1.43-2.14 $\mu \mathrm{m}$ wide. Isolates from Colletotrichum capsici, had similar olive color of Colletotrichum gloeosporioides, However, they possessed falcate conidia distinct from Colletotrichum gloeosporioides. In addition, Colletotrichum capsici formed round to ovate appresoria. The spore measurement of this species was 13.21-16.21 $\mu \mathrm{m}$ length and 1.79-3.28 $\mu \mathrm{m}$ width. Colletotrichum gloeosporioides and Colletotrichum capsici grew better on Potato Dextrose Agar (PDA) than in Malt Extract Agar (MEA) and Yeast Extract Agar (YEA). Growth rates of Colletotrichum spp. were higher under light exposure than in dark. The samples are stored as stock culture in the Institute for Tropical Biology and Conservation (ITBC), Universiti Malaysia Sabah.

\section{References}

Arauz, L.F. (2000). Mango anthracnose: Economic impact and current options for integrated management. Plant Disease 6: 600-607.

Black, L.L. \& T.C. Wang (1993-2002). Chilli anthracnose research at AVRDC 1993-2002. Asian Vegetable Research and Development Centre, Shanhua, Taiwan.http://www.avrdc.org/publications/ proceedings/abstracts_chili_anthracnose.pdf

Cano, J., J. Guarro \& J. Gene (2004). Molecular and morphological identification of Colletotrichum species of clinical interest. American Society for Microbiology 42(6): 2450-2454.

Castro, L.G.M., C. da Silva Lacaz, J. Guarro, J. Gene, E.M. HeinsVaccari, R.S. de Freitas Leite, G.L. Hernandez Arriagada, M.M. Ozaki Regueira, E. Miki Ito, N.Y. Sakai Valiente \& R.S. Nunes. (2001). Phaeohyphomycotic cyst caused by Colletotrichum crassipes. Journal of Clinical Microbiology 39: 2321-2324.

Charlie, M.J., S.C. Watkinson \& G.W. Gooday (2001). The Fungi $2^{\text {nd }}$ edition. Academic Press, United Kingdom.

Deacon, J.W. (1998). Modern mycology, 1998. English Language Book Society / Black Scientific Publication. London: 303.

De Hoog, G.S., J. Guarro, J. Gene \& M.J. Figueras (2000). Atlas of clinical fungi $2^{\text {nd }}$ edition. Centraalbureau voor Schimmelcultures, Utrecht, The Netherlands.
Ellett, C.W. (1989). Ohio Plant Disease Index. Ohio State University, Columbus.

Fernandez, V., D. Dursun, D. Miller \& E.C. Alfonso (2002). Colletotrichum keratitis. American Journal of Ophthalmology 134: 435-438.

Garrido, C., M. Carbu, F. J. Fernandez-Acero, G. Budge, I. Vallejo, A. Coyler \& J.M. Cantoral (2007). Isolation and pathogenicity of Colletotrichum spp. causing anthracnose of strawberry in south west Spain. European Journal of Plant Pathology 120: 409-415.

Gopinath, K., N.V. Radhakrishnan \& J. Jayaral (2006). Effect of propiconazole and difenoconazole on the control of anthracnose of chilli fruit caused by Colletotrichum capsici. Crop Protection 25: 10241031.

Guarro, J., T.E. Svidzinski, L. Zaror, M.H. Forjaz, J. Gene \& O. Fischman (1998). Subcutaneous Hyalohyphomycosis caused by Colletotrichum gloeosporioides. J. Clin. Microbiol. 36: 3060-3065.

Hong, J.K. \& B.K. Hwang (1998). Influence of inoculum density, wetness duration, plant age, inoculation method and cultivar resistance on infection of pepper plants by Colletotrichum coccodes. Plant Disease 82: 1079-1083.

Howard, C.M., J.L. Maas, C.K. Chandler \& E.E. Albregts (1992). Anthracnose of strawberry caused by the Colletotrichum complex in Florida. Plant Disease 76:976-981.

Kim, B.S., H.K. Park \& W.S. Lee (1990). Resistance to anthracnose (Colletotrichum spp.) in pepper. 184-188. In: Tomato and Pepper Productions in the Tropics. S. K. Green, T. D. Griggs and B. T. McLean, eds. Proc. Int. Sympos. Integr. Manag. Practices. Asian Vegetable Research and Development Centre, Shanhua, Taiwan.

Kim, W.G., E.K. Cho \& E.J. Lee (1986). Two strains of Colletotrichum gloesporioides Penz. causing anthracnose on pepper fruits. Korean Journal of Plant Pathology 2: 107-113.

Liao, W.Q., J.Z. Shao, S.Q. Li, T.Z. Li, S.X. Wo, U.Z. Zhang \& Q.T. Chen (1983). Colletotrichum dematium caused keratitis. China Medical Journal 96: 391-394.

Liesegang, T.J. \& R.K. Forster (1980). Spectrum of microbial keratitis in South Africa. American Journal of Ophthalmology 90: 38-47.

Manandhar, J.B., G.L. Hartman \& T.C. Wang (1995). Anthracnose development on pepper fruits inoculated with Colletotrichum gloeosporioides. Plant Disease 79: 380-383.

Matsuzaki, O., M. Yasuda \& M. Ichinohe (1988). Keratomycosis due to Glomerella cingulata. Review Iberian Micology 5 (Suppl. 1): 30.

Montri, P., P.W.J. Taylor \& O. Mongkolporn (2009). Pathotypes of Colletotrichum capsici, the causal agent of chilli anthracnose, in Thailand. Plant Disease 93: 17-20.

Oanh, L.T.K., V. Korpraditskul \& C. Rattanankreetakul (2004). A pathogenicity of anthracnose fungus, Colletotrichum capsici on various Thai chilli varieties. Kasetsart Journal (Natural Science) 38(6): 103108.

Photita, W., S. Lumyong, P. Lumyong \& K.D. Hyde (2001). Endophytic fungi of wild banana (Musa acuminata) at Doi Suthep Pui National Park, in Thailand. Mycological Research 105: 1508-1513.

Poonpolgul, S. \& S. Kumphai (2007). Chilli pepper anthracnose in Thailand. In: First Int. Symp. Chilli Anthracnose. Convention Center, Seoul National University, Korea: 23. http://www.avrdc.org/publications/ proceedings/abstracts_chili_anthracnose.pdf

Prusky, D. (1996). Pathogen quiescence in postharvest diseases. Annual Review of Phytopathology 34: 413-434.

Ritterband, D.C., M. Shah \& J.A. Seedor (1997). Colletotrichum graminicola: a new coneal pathogen. Cornea 16: 362-364.

Sangchote, S. (1999). Anthracnose Resistant in Chilli. Progress report at the $20^{\text {th }}$ Anniversary of Kamphaeng saen campus, Kasetsart University, $29^{\text {th }}$ November- $5^{\text {th }}$ December 1999.

Sanogo, S. (2003). Chile pepper and the threat of wilt diseases. Online. Plant Health Progress.

Sheu, Z.M., J.R. Chen \& T.C. Wang (2007). Application of ITS-RFLP analysis for identifying Colletotrichum species associated with pepper anthracnose in Taiwan. Asian Vegetable Research and Development Centre, Shanhua, Taiwan. http://www.avrdc.org/publications/ proceedings/abstracts_chili_anthracnose.pdf

Shukla, P.K., Z.A. Khan, B. Lal, P.K. Agrawal \& O.P. Srivastava (1983). Clinical and experimental keratitis caused by Colletotrichum state of Glomerella cingulata and Acrophialophora fusispora. Sabouraudia 21: 137147 . 
Takahashi, L. M., D.D. Rosa, M.A. Basseto, H.G. de Souza \& E.L. Furtado (2008). First report on Colletotrichum gloeosporioides on Hylocereus megalanthus in Brazil. Australasian Plant Disease Notes 3: 96-97.

Taylor, P. \& O. Mongkolporn (2007). Pathotypes of Colletotrichum spp. infecting chilli peppers and mechanisms of resistance. Asian Vegetable Research and Development Centre, Shanhua, Taiwan. http://www.avrdc.org/publications/proceedings/abstracts_chili_anthracnose.pdf

Than, P.P., H. Prihastuti, S. Phoulivong, P.W.J. Taylor \& Hyde, K.D. (2008). Chilli anthracnose disease caused by Colletotrichum species. Journal of Zhejiang University Science 9(10): 764-778.

Wilson, L.L., L.V. Madden \& M.A. Ellis (1992). Overwinter survival of Colletotrichum acutatum in infected strawberry fruit in Ohio. Plant Disease 76: 948-950.

Yamamoto, N., T. Matsumoto \& Y. Ishibashi (2001). Fungal keratitis caused by Colletotrichum gloeosporioides. Cornea 20: 902-903.
Author Details: HA KwAN Yun completed her BSc (Hons) in Conservation Biology at the Institute for Tropical Biology and Conservation, Universiti Malaysia Sabah, Malaysia. Her thesis was on Morphological and Physiological Characterization of Colletotrichum spp. Isolated from Capsicum spp. (Chillies) in Sabah.

Abdul Hamid Ahmad is the Director of the Institute for Tropical Biology and Conservation, Universiti Malaysia Sabah.

SEPIAH MUID is a senior lecturer from Universiti Malaysia Sarawak. She has been working on taxonomy and systematics of Borneon fungi and mushrooms for the past 20 years.

Jaya Seelan Sathiya Seelan is presently working as a researcher/tutor at the Institute for Tropical Biology and Conservation. He has been involved in mushroom and fungi related research for the past seven years and graduated in the field of fungal biotechnology from Universiti Malaysia Sarawak, Malaysia. 